\title{
Present at the Beginning of a New Era for Antitrust: \\ Reflections on 1982-1983
}

by

Lawrence J. White

EC-99-03 


\title{
PRESENT AT THE BEGINNING OF A NEW ERA FOR ANTITRUST:
}

REFLECTIONS ON 1982-1983

\author{
Lawrence J. White \\ Stern School of Business \\ New York University \\ 44 West 4th Street \\ New York, NY 10012-1126 \\ Tel: 212-998-0880 \\ Fax: 212-995-4218 \\ e-mail: lwhite@stern.nyu.edu
}

Forthcoming: Review of Industrial Organization

Revised draft, 3/16/99

Comments welcomed

\footnotetext{
* An earlier draft of this paper was presented at the 25th Anniversary Seminar of the Economic Policy Office/Economic Analysis Group of the Antitrust Division, U.S. Department of Justice, on November 6, 1998. Thanks are due to Christopher Anderson, Timothy Brennan, Dale Collins, William Comanor, Curtis Jernigan, Russell Pittman, Constance Robinson, Elliott Seiden, Bruce Snapp, and Gregory Werden for helpful comments on an earlier draft. In memorium: William Baxter died three weeks after that seminar, on November 28, 1998.
} 


\title{
PRESENT AT THE BEGINNING OF A NEW ERA FOR ANTITRUST:
}

REFLECTIONS ON 1982-1983

\begin{abstract}
$\underline{\text { Abstract }}$
The early 1980s were an important time of transition for antitrust policy for the Antitrust Division of the U.S. Department of Justice. I had the privilege to be selected to serve as the first "Chief Economist" for the newly installed Assistant Attorney General for Antitrust, William F. Baxter. In this essay I discuss some of the important achievements of that period, as well as some missed opportunities.
\end{abstract}

Key words: Antitrust; mergers; price-fixing; monopolization 


\section{PRESENT AT THE BEGINNING OF A NEW ERA FOR ANTITRUST: \\ REFLECTIONS ON 1982-1983}

\section{Introduction}

The early 1980s were an important time of transition for antitrust policy for the Antitrust Division of the U.S. Department of Justice (DOJ). With a new presidential administration came a new Assistant Attorney General (AAG) for Antitrust, William F. Baxter. I had the privilege of being selected by Baxter to serve as his first "Chief Economist" in the capacity of the Director of the Economic Policy Office (EPO) of the Division from mid January 1982 through the end of August 1983.

The changes in antitrust policy and enforcement were neither as sharp as some critics alleged (and as some enthusiasts proclaimed) nor as mild as some "gradualists" might argue. Nevertheless, there were important initiatives and changes that occurred during that period, as well as some missed opportunities. In the remainder of this essay I will first discuss some of the major achievements of that period, almost all of which involved active participation by the economists of the EPO, and then discuss some of the disappointments and missed opportunities.

\section{The Achievements}

\section{The Merger Guidelines, and market definition.}

A major achievement of the early Baxter period was the development and promulgation of the Merger Guidelines, which were issued in June 1982. These Guidelines were technically a revision of the Guidelines that had been issued in 1968. But the 1982 document was so different in conceptual 
structure from its predecessor that few participants or commentators seriously thought of it as a "revision;" instead, we all considered it to be a new document with a new approach. These Guidelines were subsequently revised in 1984 and 1992, with a small modification in 1997; but their essential structure has remained intact in the seventeen years since their initial development.

Surely the most important advance in the Guidelines was the market delineation (or definition) paradigm. Prior to that time the conceptual basis for market delineation was, at best, limited. Most industrial organization economists understood that the definition of markets rested on cross-elasticities of supply and demand: "The economic concept of a market is stated in terms of the behavior of buyers and sellers. Two products belong in the same market if a small change in price (or product) causes a significant diversion in a relatively short time of the buyers' purchases or the sellers' production from one product to another." (Kaysen and Turner, 1959, pp. 27-28). Some empirical "rules of thumb" had been offered (Elzinga and Hogarty, 1973; and Horowitz, 1981). Market delineation for merger analysis and enforcement by the Division and by the FTC was largely ad hoc. ${ }^{1}$

By contrast, the Guidelines offered a more solid conceptual foundation for market delineation: ${ }^{2}$ Since the primary concern of merger enforcement is the prevention of mergers that create or enhance market power, the appropriate or relevant market for merger analysis should generally be the smallest

\footnotetext{
${ }^{1}$ I can remember attending a seminar presentation on antitrust policy by George Hay, then Director of EPO, in the spring of 1979 in which he described the market definition processes as being ad hoc and in which indicia such as the presence of a trade association or an industry journal would be important.

${ }^{2}$ As Werden (1993) has pointed out, Adelman (1959) had earlier suggested a similar formulation; but (as of 1982) there was no one at the Division who knew of Adelman's suggestion. And though there apparently was an oral tradition concerning market definition that developed during George Hay's tenure (1972-1979) as Director of the EPO, it was not readily accessible in early 1982.
} 
group of sellers that, if they coordinated their actions, could successfully (profitably) exercise market power -- e.g., by raising prices by a small but significant amount and sustaining that higher level for a significant period of time. To be successful, this effort at collective exercise of market power would not be thwarted by a sufficient number of buyers switching away to sellers of substitute products or to sellers of the same product located elsewhere. In essence, a relevant market is one that can be successfully monopolized.

The focus on the sellers was an essential part of the paradigm; again, since the policy concern is the exercise of market power and since it is sellers that exercise market power, the focus on sellers was crucial. But, where price discrimination among groups of buyers might be possible, then the identification of a separate buyer group (identified by geographic location or by function -- e.g., wholesalers versus retailers) who might be the subject of the exercise of market power by the identified group of sellers also constituted a relevant market.

The market delineation paradigm did not solve the problems of how to gather the data that would be crucial for the empirical determination of markets for actual enforcement. But it offered, for the first time in a widely available policy-relevant document, sensible guidance as to the right questions to be asked.

With the conceptual potential for monopolization established, the remainder of the Guidelines established (along the lines suggested by Stigler [1964]) the principles that would help determine the likelihoods of the post-merger exercise of market power: Were the merger partners selling in the same market(s)? What would be the post-merger level of overall seller concentration in each relevant market, measured in terms of the Herfindahl-Hirschman Index (HHI)? What changes in seller concentration would occur as a consequence of the merger? How easy is entry? Are there other 
characteristics of the market -- the nature of the product, the numbers and types of buyers, the histories and characteristics of the sellers -- that would make the post-merger exercise of market power more or less likely? And, in the spirit of Williamson (1968), are there readily identifiable efficiencies that would arise from the merger that would provide a sufficient offset to any perceived likelihoods of the exercise of market power. ${ }^{3}$

The first time that the Guidelines' market delineation paradigm was actually used for merger enforcement, in June of 1982, was not a resounding success. ${ }^{4}$ The Division challenged a merger between two modest-sized banks in southwestern Virginia, ${ }^{5}$ and actually did conduct a survey among bank customers to try to determine the likelihoods of customers switching away to other banks in the face of a rise in loan interest rates or a fall in deposit interest rates. But Federal District Court Judge Glen Williams was not convinced by the evidence, and the Division lost. ${ }^{6}$

Perhaps the best empirical implementation thus far of the Guidelines' market delineation paradigm came in the FTC's 1997 challenge to the merger of Staples and Office Depot (Baker, 1998; Dalkir and Warren-Boulton, 1999). ${ }^{7}$ At first glance the merger might have seemed unobjectionable,

3 The 1982 version of the Guidelines embodied a skeptical attitude toward merger partners' promises of efficiencies. Subsequent versions have been somewhat more tolerant.

${ }^{4}$ See U.S. v. Virginia National Bankshares, Inc., 1982-2 Trade Cases 64,871.

${ }^{5}$ Ironically, this was one of the few cases where the Division was arguing for larger geographic markets and the defendants were arguing for smaller markets (and claiming that each of the merger partners were in separate, small markets and therefore did not compete with each other).

${ }^{6}$ A few years later, however, when the FTC challenged the proposed merger of Coca-Cola and Dr Pepper, the Guidelines' structure and its market delineation paradigm importantly structured the FTC's presentation of its case (White 1994, 1999b) and even Coca-Cola's defense; this time the Government prevailed in Federal District Court.

${ }^{7}$ For a different view, see Werden (1999). 
since the two merger partners accounted for only a small percentage of all retail sales of office supply products. But simple price comparisons, as well as more sophisticated econometrics, demonstrated that office supply superstores' (OSSs) sales in individual metropolitan areas constituted separate relevant markets: Where Staples or Office Depot was alone in a metropolitan area, its prices tended to be higher than when a second OSS was also selling in the area, and prices were lower still when a third OSS (Office Max) was in the area. Market power could be and was in fact being exercised by OSSs in these metropolitan areas. Hence, they were relevant markets (and the merger would greatly exacerbate seller concentration in these markets). ${ }^{8}$ Federal District Court Judge Thomas Hogan was convinced, and the FTC won. ${ }^{9}$

If longevity is a relevant indicator, it is worth noting that (as of early 1999) the 1982 Guidelines (with revisions) have now outlasted their 1968 predecessor by almost three years and still appear to be providing strong guidance for merger analysis and enforcement.

\section{AT\&T.}

The AT\&T case had been filed in October 1974 and had percolated for 6-1/2 years before Baxter came to the Division. Believing strongly in the case, he vowed to "litigate it to the eyeballs" (Temin, 1987, p. 225). After AT\&T's motion for summary judgment was harshly rejected by Judge Harold Greene in September 1981, ${ }^{10}$ AT\&T quickly capitulated and settled on terms that achieved virtually all of the Division's goals: ${ }^{11}$ the separation of the regulated monopoly local service markets

\footnotetext{
${ }^{8}$ For a different view, see Hausman and Leonard (1997).

${ }^{9}$ F.T.C. v. Staples, 970 F. Supp. 1066.

${ }^{10}$ U.S. v. AT\&T, 524 F. Supp. 1336 (1981).

${ }^{11}$ The settlement was announced on January 8, 1982, two weeks before I came to the Division. A
} 
from the actually or potentially competitive equipment and long-distance service markets, since AT\&T's control of the bottleneck local service, in conjunction with imperfect regulation of that service, was likely to cause AT\&T to distort and impede competition in the latter markets to benefit itself (Brennan, 1987, 1990, 1995; Noll and Owen, 1994). The settlement was implemented on January 1, 1984, and succeeded in restructuring the entire face of American telephone service (Temin, 1987). ${ }^{12}$

Unfortunately, the Division in the mid 1980s began to back away from the core principle that had underlay the case and its settlement: keeping the regulated local service bottleneck monopolies out of the competitive services. By the early 1990s, however, the Division had returned to its earlier stance. The Telecommunications Act of 1996 continued to embody the basic spirit of the settlement, though its supporters hoped to achieve the best of both worlds by encouraging entry into local service and in turn allowing the local service providers into long distance. Over three years later the Act has achieved neither.

\section{Vertical restraints.}

Perhaps the largest change in antitrust policy was occurring in the area of vertical restraints. Though the Supreme Court, in GTE-Sylvania ${ }^{13}$ in 1977, had declared territorial restraints to be subject to a rule-of-reason analysis (and not a per se violation, as it had declared only ten years earlier in

prior conflict (I had consulted briefly for AT\&T on the case in 1977) caused me to be recused from the detailed discussions in 1982-1983 that implemented the basic settlement.

${ }^{12}$ Along with the corporate restructuring came greater transparency as to the cross-subsidy that had been embedded in telephone prices. The implicit "separations" allocations of the pre-divestiture AT\&T were replaced by explicit access charges that were mandated by the FCC and paid by the long-distance companies to the local operating companies. 
$\underline{\text { Schwinn }}^{14}$ ) and the Court had been slowly backing away from the harsh per se approach that it had applied in 1958 to tying in Northern Pacific, ${ }^{15}$ antitrust policy was still generally hostile to vertical restraints. All forms of resale price maintenance (RPM) were still per se illegal and were often described as "vertical price-fixing" (which conveyed the impression that RPM was the conceptual equivalent of "smoke-filled-room" horizontal price fixing among competitors), and the Division had succeeded in a criminal conviction of Cuisinarts in an RPM case in 1980.

Baxter, by contrast, was a believer in the generally benign nature of most vertical relationships. ${ }^{16}$ For example, he understood and appreciated the Telser (1960) explanation of RPM: as a manufacturer's response to the problems of free riding on information provision by distributors. The Division -- much to the consternation of many in Congress ${ }^{17}$-- ceased bringing vertical restraints $\operatorname{cases}^{18}$ and entered amicus briefs in favor of the defendants in a major tying case (Jefferson Parish ${ }^{19}$ )

${ }^{13}$ Continental T.V. v. GTE Sylvania, 433 U.S. 36 (1977); see also Preston (1994).

${ }^{14}$ U.S. v. Arnold, Schwinn and Co., et al., 388 U.S. 365 (1967).

${ }^{15}$ Northern Pacific Railway Co. v. U.S., 356 U.S. 1 (1958).

${ }^{16}$ For a broad overview of how economics and legal thinking had changed with respect to vertical restraints by the 1980s, see White (1989). For my views on vertical restraints at the time, see White (1981, 1985a, 1989).

17 Often overlooked in the Congressional criticism of Baxter's enforcement policies was the continuing vigorous effort by the Division in prosecuting horizontal price-fixing conspiracies among competing sellers, including hundreds of convictions of highway construction companies and individuals.

${ }^{18}$ It is worth noting that the Division did stop a proposed merger that had a heavy vertical element; see the text below.

19 Jefferson Parish Hospital District No. 2 v.Edwin G. Hyde, 466 U.S. 2 (1984); see also Lynk (1999). 
and a major RPM case $\left(\underline{\text { Monsanto }}^{20}\right)$. The latter brief caused so much consternation on Capitol Hill that a specific law (P.L. No. 98-166, Sec. 510) was passed to prevent the Division, in its oral argument before the Supreme Court in Monsanto, from advocating any alteration (e.g., to a rule-of-reason standard) in the Court's per se violation treatment of RPM.

Despite the Congress's fulminations, the Division and the FTC continued to refrain from bringing vertical restraints cases through the remainder of the 1980s. In 1985 the Division promulgated a set of Vertical Restraints Guidelines that tried to provide clarity and guidance in the vertical area and that clearly embodied a tolerant enforcement philosophy. However, the Division withdrew these Guidelines in 1993, and since then the Division and the FTC have brought some vertical restraints cases, though more sparingly than had been true prior to 1981 .

As for Monsanto, the Court (while finding the defendant Monsanto guilty and retaining the per se treatment of RPM) did increase the evidentiary burden on plaintiffs in order to find a defendant guilty of an RPM violation, and the Court increased the evidentiary burden still further four years later in Sharp. ${ }^{21}$ Though the entire Court found in favor of the defendant in Jefferson Parish (on the grounds that the defendant hospital did not possess market power), it narrowly (by a vote of 5-4) maintained a formalistic posture of per se treatment of tying; the minority wanted instead to introduce a rule-ofreason standard. The Court's 1992 decision in another tying case, Kodak, ${ }^{22}$ may have been a step

${ }^{20}$ Monsanto Co. v.Spray-Rite Service Corp., 465 U.S. 752 (1984); see also Warren-Boulton (1999).

${ }^{21}$ Business Electronics Corp. v. Sharp Electronics Corp., 485 U.S. 717 (1988).

${ }^{22}$ Eastman Kodak Co. v. Image Technical Services, Inc., 504 U.S. 451 (1992); see also MacKieMason and Metzler (1999). 
back. $^{23}$ But in a 1997 decision in another RPM case, State Oil Co., ${ }^{24}$ the Court reversed its earlier $\left(\underline{A l b r e c h t}^{25}\right)$ per se violation standard for the practice of maximum RPM and established a rule-ofreason standard for the practice of maximum RPM. This may be (as RPM's enthusiasts hope and its critics fear) a first step toward a reevaluation of RPM more generally.

Perhaps antitrust policy would have reached its current position regardless of who occupied the Assistant Attorney General's office in the early 1980s; but it seems more likely that Baxter's views and actions accelerated the process.

\section{Invitations to fix prices.}

As many undergraduate students of intermediate microeconomics have known for the past decade (Pindyck and Rubinfeld, 1997, pp. 369-370, and earlier editions), in February of 1982 the President and CEO of American Airlines, Robert Crandall, suggested in a telephone conversation with the President and CEO of Braniff Airlines, Howard Putnam, that Braniff should raise its air fares by $20 \%$ and that American would follow "the next morning." Braniff subsequently brought a tape of the telephone conversation to the Division. ${ }^{26}$

The Division decided that it could not bring Sherman Act Section 1 price-fixing charges against American and Crandall, since there had not been any actual or even attempted joint effort at price

${ }^{23}$ As MacKie-Mason and Metzler (1999) remind us, however, the narrow focus of the Court's decision in Kodak concerned the burden on the defendant that was necessary to sustain a motion for summary judgment in a case of this sort.

${ }^{24}$ State Oil Co. v. Khan, 66 L.W. 4001 (1997).

${ }^{25}$ Albrecht v. Herald Co., 390 U.S. 145 (1968).

${ }^{26}$ Braniff at the time was facing hard times financially, had filed a predatory pricing suit against American, and was hoping for any help that it could get from any quarter. 
fixing (i.e., no "contract, combination, or conspiracy in restraint of trade") -- only an invitation or solicitation. But in a novel use of Section 2 of the Sherman Act the Division in 1983 brought an attempted monopolization case against American and Crandall: Since American and Braniff together accounted for a high fraction of the flights and passengers in a number of city-pair air transportation markets in the southwestern U.S., the attempted monopolization would have succeeded if Braniff had agreed to raising prices. Though the defendants won a motion for summary judgment at the Federal District Court level, the Fifth Circuit Court of Appeals reversed and ordered a trial. ${ }^{27}$ American and Crandall subsequently settled, with promises never to do it again combined with reporting obligations. Though the settlement might have been a bit weak, the Fifth Circuit's precedent was an important one.

Included in the Division's 1998 case against Microsoft is the allegation that in a June 21, 1998, meeting between the senior managers of Microsoft and Netscape the former made an offer to divide the market for Internet browsers between the two companies. ${ }^{28}$ Though the American/Crandall precedent involved an invitation to an agreement on pricing and the alleged Microsoft incident involves an invitation to an agreement to allocate a market, it seems highly likely that the precedent will indeed be important.

\section{Stopping a vertical merger.}

Though generally quite reluctant to bring vertical restraints cases, the Division did block a merger that had substantial vertical elements. As of 1982 the three major cable TV channels that primarily showed recent movies as their staple fare were HBO (owned by Time, Inc.), Showtime

\footnotetext{
${ }^{27}$ U.S. v. American Airlines, Inc. and Robert L. Crandall, 743 F. 2d 1114.

${ }^{28}$ See Lohr (1998) for a journalistic account.
} 
(owned by Viacom), and The Movie Channel (TMC) (owned by Warner Communications and American Express). ${ }^{29}$ In November 1982 Paramount Pictures, Universal Studios, Warner, and American Express proposed a joint venture that would own and operate TMC. In January 1983 Viacom entered the picture, and the proposal then involved a merger of Showtime and TMC, with the three movie studios, Viacom, and American Express jointly owning the merged entity. Thus, three of the six major film studios would be co-owners of the joint venture.

In June 1983 the Division indicated its objections to the merger and joint venture. Though the Division's specific grounds were never publicly stated, the vertical arrangement between the venture and the film studios provided the entity with an opportunity to raise rivals' costs (Salop and Scheffman, 1983, 1987), disadvantage $\mathrm{HBO}$ and potential entrants, and distort competition in the showing of recent movies on cable (White, 1985b). Paramount and Universal subsequently withdrew from the venture, and the Division withdrew its objections.

To my knowledge, this was the only vertical merger challenged by the Division or the FTC during the 1980s. In the 1990s both agencies' renewed interest in vertical issues generated a renewed concern about vertical mergers (Morse, 1998). In most instances where either agency challenged a vertical merger, a consent decree with modest contractual or behavioral requirements settled the matter and permitted the merger to proceed. ${ }^{30}$ Only in 1998 did the DOJ challenge two mergers that required

\footnotetext{
${ }^{29}$ The three services accounted for $60 \%, 20 \%$, and $10 \%$ of pay TV subscriptions.

${ }^{30}$ For discussions of two vertical cases -- Lockheed and Martin Marietta (1995); and Time Warner and Turner Broadcasting (1996) -- that were approved by the FTC with modest behavioral and contractual conditions imposed, see Nelson and Stoner (1999) and Besen et al. (1999), respectively. For brief discussions of other vertical mergers that eventually received consent-decree approval by the DOJ or the FTC, see Morse (1998).
} 
a substantial divestiture before being permitted to proceed (Enova and Pacific Enterprises) or that simply was dropped (Lockheed and Northrup). ${ }^{31}$

6. Dropping the IBM case.

On January 8, 1982, the same day that he announced the AT\&T settlement, Baxter also announced his attention to drop the Division's thirteen-year-old IBM prosecution. Though the merits of the Division's original case against IBM might be debated (Brock, 1975; Fisher et al., 1983; Pittman, 1984; DeLamarter, 1986), it is clear that by 1982 the computer industry had changed substantially from the structure-behavior-performance picture of the 1960s that had given rise to the suit. The suit had lasted for far too long without even reaching an initial decision by Federal District Court Judge David Edelstein and had consumed far too much of the Division's resources and attention; the analogy that many commentators have offered -- that the IBM case was the Division's Vietnam War -- is an apt one. Unfortunately, no solution comparable to Senator George Aiken's (paraphrased) suggestion for ending the real war -- "Declare victory and bring the troops home" -- was available.

Dropping the case was the best available solution.

\section{Administrative/managerial issues}

Despite many critics' claims that the economists were in the ascendancy at the Division, I quickly discovered in early 1982 that the Division was still very much a legal organization that was run by lawyers. Baxter might be more sympathetic to economics arguments than were his predecessors, and economists just might have a deserved reputation as "case killers" in the area of vertical restraints. Still, the EPO was just an "island" of about 40 economists in an "ocean" of about 300 lawyers. Crucial

${ }^{31}$ As Morse (1998) points out, two earlier proposed mergers received FTC challenges that would have required divestitures, but the mergers failed to proceed for other reasons. 
decisions were, in the end, always made by lawyers. Indeed, as of 1981 the Division's organization showed that the Director of EPO reported to the Deputy AAG for Regulation rather than directly to the AAG.

In my pre-appointment discussions with Baxter I asked that the position of EPO Director be elevated to that of Deputy AAG; Baxter demurred, arguing that the political and bureaucratic problems within the DOJ would be too great. As a fall-back position I asked that the organization chart of the Division be redrawn to show the EPO Director as reporting directly to the AAG, as an alternative way of assuring that economists would have direct access to the Division's decision-making process (and as a way of strengthening that link for future EPO Directors and AAGs); Baxter agreed. I was quite pleased when my successor, Frederick Warren-Boulton, convinced Douglas Ginsberg, then AAG, that the position should be elevated to Deputy AAG, where it remains today.

\section{The Disappointments ${ }^{32}$}

1. Market delineation for monopolization cases. ${ }^{33}$

There has been no progress in developing a market delineation paradigm, comparable to the Merger Guidelines' market delineation paradigm, for cases in which monopolization, or the exercise of

\footnotetext{
${ }^{32}$ As will be clear from the text below I have included here a mixture of disappointments over decisions that were taken at the time and frustrations (some involving "20/20 hindsight") at the lack of legal and/or economics progress since then.

${ }^{33}$ In White (1999a) I expand further on this theme.
} 
market power, is alleged. ${ }^{34}$ In the absence of a paradigm, however, the following conundrum arises: It is a core proposition in microeconomics that a profit-maximizing monopolist will maintain its price at a level (as compared with an otherwise similar group of competitors) that is higher and in doing so experiences a lower volume of sales than the competitive industry would have experienced. In essence, the monopolist maintains its price at a level that implies the loss of sales (to other sellers of something) as compared with the outcome for the competitive industry. Equivalently, the monopolist can always claim, truthfully, that it faces "competition" from other firms and that if it tried to raise its price from current levels it would lose too many sales to those firms. The Merger Guidelines' market delineation paradigm, based on a prospective price increase, is thus not applicable for the delineation of the market of a monopolist (or, equivalently, for the determination of the existence of market power).

As a consequence, any entity that is accused of having market power ${ }^{35}$ can and will always claim that it faces competitors, that these competitors ought to be included within any delineation of a relevant market, and that the entity therefore does not possess market power. A failure to recognize that this presence of competitors may be the consequence of market power (i.e., the maintenance of price above the competitive level) has frequently been termed the "cellophane fallacy," referring to a 1956 Supreme Court decision. ${ }^{36}$

${ }^{34}$ These cases, of course, run the gamut from simple monopolization through predatory behavior and vertical restraints. A threshold issue in many of the cases in the latter two categories is whether the defendant has market power.

${ }^{35}$ As Werden (1999) points out, where the plaintiff is complaining about prospective actions by the defendant, the Merger Guidelines' market delineation paradigm may well be applicable, since the relevant question (in essence) would be, "Will this prospective action make things worse (e.g., allow prices to be raised)?"

${ }^{36}$ U.S. v. E.I. Du Pont de Nemours and Co., 351 U.S. 377 (1956). The DOJ claimed that Du Pont 
A natural supplementary piece of information would seem to be the profits of the monopolist. But, since the early 1980s a set of critiques (Benston, 1982; Fisher and McGowan, 1983; Fisher, 1984) have argued that the standard accounting data that are used to report corporate profits are unreliable indicators of true economic profits, casting doubt on this route to the demonstration of market power.

Efforts to demonstrate that a firm is exercising market power thus face a quandary: Both a true monopolist and a firm that truly has no market power will be observed to face competitors, and profit data may not be reliable enough to establish the former's excess profits. Crucial here is the absence of a market delineation paradigm that would somehow specify market boundaries that are free of the distortions created by a monopolist's elevated price. ${ }^{37}$

In some instances, as in the Staples case discussed above, the availability of price data at the local or regional level, along with data on local seller concentration and other relevant variables, may allow tests for the existence of markets and market power. But the presence of a guiding paradigm would surely help structure the empirical analysis for monopolization inquiries.

Perhaps the goal of developing a market delineation paradigm for monopolization purposes is utopian. But its absence will guaranty a continued pattern of arbitrary and erratic outcomes in antitrust cases involving allegations of monopolization.

had a monopoly of cellophane; Du Pont claimed that the relevant market was "flexible wrapping materials," of which it had only a modest share. The Supreme Court decided in Du Pont's favor, ignoring information that indicated that it was Du Pont's elevated price (which yielded above-normal profits) that caused other flexible wrapping materials to be competitive with cellophane. See Stocking and Mueller (1955). For a more recent discussion (of the IBM case) that commits the same fallacy, see Fisher et al. (1983).

${ }^{37}$ It would seem that a solution to this dilemma would be to try to specify which firms would be in competition with an alleged monopolist if the latter sold at lower prices that reflected only normal profits. But this approach again runs aground on the problem of profit measurement. 


\section{The GTE-Sprint merger.}

In October 1982 GTE proposed to purchase Sprint from the Southern Pacific Company. Prior to the break-up of AT\&T, GTE was the second largest provide of local telephone service in the U.S., with pockets of local service scattered across the country. Sprint was the second largest "independent" (i.e., non-AT\&T) provider of long-distance service (after MCI).

The theory that underlay the AT\&T divestiture pointed toward the potential anti-competitive consequences of this merger: GTE could use its position as the provider of regulated bottleneck monopoly local service to distort competition and to favor its Sprint subsidiary with respect to the long-distance calls originated (and possibly even those terminated) in its local service areas. But, unlike the AT\&T case, there were no "smoking guns," no history and stories of bad behavior by GTE. However, the AT\&T case had been a Sherman Act Section 2 monopolization case, whereas the proposed merger was being considered under Section 7 of the Clayton Act, and enforcement of Section 7 is based on likelihoods of prospective anti-competitive behavior. Smoking guns should not have been necessary. And the AT\&T theory and evidence pointed toward those likelihoods.

Nevertheless, the Division decided not to oppose the merger. At least part of the reason was fears that an unfavorable judicial decision in a challenge to the GTE-Sprint merger might cause the AT\&T settlement to be re-opened, judicially or politically, and the Division's substantial achievement in that settlement might be lost. The Division settled for a mild consent decree in which GTE promised to operate Sprint as a separate subsidiary and not to discriminate against other long-distance carriers.

Ironically, in a part of the litigation that followed the Telecommunications Act of 1996 and delayed its implementation, SBC (one of the local Bell operating companies -- i.e., one of the AT\&T "offspring") claimed that the Act unfairly and unconstitutionally discriminated against the local Bell 
operating companies, since other (non-Bell) local operating companies (like GTE) are not subject to the same requirements to open their networks to entrants and to the same constraints on entering longdistance service. $^{38}$ If the Division had decided to oppose the GTE-Sprint merger (and had succeeded), this argument would have had less force.

3. AT\&T and cellular telephone service.

After a decade of regulatory delay, the Federal Communications Commission (FCC) in the early 1980s finally decided to authorize the provision of cellular telephone service (Hausman 1997). The FCC's initial approach was to allocate two cellular service licenses to each major metropolitan area and to insist that one of those licenses in each area should be assigned to the local "wireline" company, which in most instances would be the local AT\&T subsidiary. The FCC reasoned that the local companies were in the best position technologically to offer the service, thereby encouraging its rapid development.

In the AT\&T divestiture that split the local Bell operating companies from AT\&T's longdistance and equipment operations, the cellular services stayed with the local operating companies. It is not clear whether this was a conscious decision or whether cellular was just automatically deemed to be local.

However, the Division instead might have insisted that all cellular services should stay with AT\&T. It is unlikely that the FCC would have objected, since its major concern was technological competence (and AT\&T surely was thought to have that). And it seems unlikely that the AT\&T

${ }^{38}$ SBC ultimately lost its legal battle, though it did succeed in delaying the implementation of the Telecommunications Act. See SBC Communications v. FCC, No. 98-10140 (5th Circuit, September 23, 1998). 
negotiators would have objected strongly.

The consequence would have been two separate companies, other than the local operating company, offering cellular service. It seems likely that competition would have been sharper. This surely was a missed opportunity.

\section{Building on the American/Crandall precedent.}

As was discussed above, the American/Crandall case was an innovative and important victory for the Division. But since then there have been only a few low-profile DOJ cases ${ }^{39}$ and a few lowprofile FTC consent decrees. ${ }^{40}$ Only in the DOJ's prosecution of the Microsoft case has the invitationto-collude issue gained a high profile.

Why this relative lack of use? It is clear that any invitations to raise prices or to divide markets are going to be private communications. Either they will be agreed to, and then if the conspirators are caught, it is the agreement that will be the subject of the prosecution; or they will be rebuffed, in which case the parties most likely will go their separate ways, and there is no strong incentive for the recipient to report the invitation to the Division or the Commission. It takes a disgruntled recipient (like Braniff or Netscape) to consider a report to the antitrust authorities to be worthwhile.

So, have there simply been few such rebuffed invitations? Or just few disgruntled recipients? Without more information, it is impossible to know. It seems unlikely, however, that such invitations are few, since this would imply that virtually all invitations to price fixing are accepted. ${ }^{41}$ And the

${ }^{39}$ See, for example, U.S. v. Ames Sintering Co., 927 F.2d 232 (1990).

${ }^{40}$ See, for example, "Decision and Order," In the Matter of Precision Moulding Co. Inc., FTC Docket No. C-3682 (September 3, 1996).

${ }^{41}$ We start out, however, not knowing the total volume of invitations, since we learn primarily 
potential social harm from such invitations is high. They are dangerous because they are private and hard to detect, as is any subsequent agreement; indeed, the difficulty in detecting price-fixing arrangements is the major justification for the treble damages penalty structure (Becker 1968; Becker and Stigler 1974).

Perhaps such rebuffed invitations really are rare, in which case there is little to worry about. Since this is unlikely and the invitations are dangerous, the Division should publicize more effectively the anti-social and illegal nature of such invitations (e.g., by "high-profiling" such prosecutions) and should devise ways to induce the recipients of such invitations to report them to the Division. Bounties for evidence leading to successful prosecutions are certainly one possibility.

\section{Clarifying predatory behavior.}

Distinguishing predatory pricing and other predatory behavior, on the one hand, from merely aggressive competitive behavior, on the other hand, has been a continuing problem for antitrust policy. The Areeda-Turner rule (Areeda and Turner, 1975) has helped, as have other innovations. Still, the problem remains, as is revealed by the differing views of Microsoft's behavior that have emerged in the Division's 1998 suit against Microsoft.

There are, however, some behaviors that even sharp critics of antitrust policy would consider predatory and worthy of condemnation: dynamiting a rival's factory, for example. In 1982 the Division had a potential opportunity to establish at least one bound on aggressive behavior, by pursuing a case that (in this author's opinion) involved behavior that was akin to dynamiting.

The case came to the attention of the Division through an article in the Columbia Journalism

about the invitations that are made, accepted, and then detected and prosecuted. 
Review (Tate 1981). Briefly, in 1974 the Gannett newspaper group acquired two daily newspapers in Salem, Oregon: the Oregon Statesman and the Capital Journal. The two papers had been previously separately owned but had joined their non-editorial operations in 1954. Subsequent to the 1974 acquisition, Gannett raised advertising rates substantially, which alienated local advertisers who then urged a Portland-based publisher of community weeklies to begin publishing in Salem. The latter company began publishing a free weekly, the Community Press, in March 1976 and attracted a substantial amount of local advertising; the Community Press soon expanded to twice-a-week publication.

Gannett, dismayed by the losses of advertising to its new rival, in June appointed a new publisher in Salem and a new marketing director. This new local leadership took an aggressive approach toward the Community Press, launching "operation demolition," which had as its goal "to fatally cripple The Community Press." ${ }^{42}$ Besides "normal" aggressive sales efforts to re-attract advertisers to the Gannett papers, the marketing director also established a bonus system for sales representatives who could show simply that they had caused an advertiser to cease using the Community Press, regardless of whether the advertiser instead used the Gannett papers.

Gannett's campaign eventually succeeded. The Community Press ceased publication in September 1978 and filed state and federal antitrust suits against Gannett. The suits were eventually settled, with the documents sealed by court order (although some of them were accidently made public).

By the time that the incident came to the attention of the Division the statute-of-limitations

\footnotetext{
${ }^{42}$ These phrases were used in Gannett documents.
} 
four-year limit on the ability to prosecute Gannett's actions was expiring, or might have already expired; the information available to the Division was murky. The Division declined to act.

In my view, the act of rewarding sales representatives for simply showing that they had removed advertising from a rival newspaper is perilously close to dynamiting a rival's factory. It is difficult to see any offsetting social gain that is achieved by such actions. A successful prosecution of Gannett would have established at least one clear boundary in an otherwise murky area. ${ }^{43}$

\section{Structuring incentives in divestitures.}

A difficult issue that arose during 1982-1983 in some merger negotiations between prospective merger partners and the Division and that is a recurring problem for the Division (and the FTC) in merger enforcement involves requirements for the divestiture of duplicative facilities so as to lessen seller concentrations in relevant markets. The problem also arises when monopolists are required to divest facilities, though the latter event occurs far less frequently.

In such situations the incentives of the Division and of the merging parties diverge sharply. The Division would like the entity that buys the facilities to be the most vigorous competitor possible; the merging parties would like the entity to be the weakest competitor possible -- ideally, one that fails immediately. ${ }^{44}$ These considerations will influence not only the seller's preference as to the buyer of the

${ }^{43}$ Also, from a strategic perspective the timing of the suit would have been propitious, since Gannett was then launching its new USA Today and would have likely been eager to avoid a continuing stream of bad publicity and reach an accommodation with the Division (which the Division nevertheless could have used as a precedent to put others on notice).

${ }^{44}$ Alternatively, the merging parties might want to sell the facilities to a new entity that will go along with collusive activities. Again, this is at odds with the Division's goals. 
facilities but also the structuring of exactly what is sold and how attractive and viable it is. ${ }^{45}$

Similarly, if a firm is exiting an industry (e.g., a failing firm or simply a firm that does not foresee successful outcomes in the industry) and is trying to sell its assets, an incumbent that has market power will place a higher value on the assets (since their purchase will help the incumbent to preserve its excess profits) than will any challenger (since the challenger's expectations would be a more competitive environment). The selling firm would prefer to sell at the higher price to the incumbent with market power; the Division would prefer a sale to the challenger.

In both types of situations the Division must adopt a highly regulatory posture, making detailed choices about purchasers and the viability of competition. Instead, the ideal would be the development of some form of an incentive-compatible mechanism whereby the seller's incentives were aligned with those of the Division, and the Division could step back and let the seller's (properly aligned) incentives drive the process.

Unfortunately, to my knowledge no such mechanism has been developed. Perhaps this goal is utopian. But in its absence, the regulatory posture will continue.

7. Distinguishing vertical restraints from conspiracies.

As was the practice both before and after the Baxter era, the Division had an active program of entering amicus briefs in private antitrust cases that the Division thought were important and where its brief might help clarify issues and influence decisions in sensible directions. Amicus briefs might be entered in cases being considered by the Supreme Court or even by the various circuit courts of appeal.

${ }^{45}$ The seller's receipt of the proceeds from the sale of the facilities may provide a partial offset; presumably, a buyer that is more optimistic about its prospective viability would be willing to pay more than a buyer that was more pessimistic. But the proceeds from the sale cannot completely offset the reductions in profits that would accompany more vigorous competition by a more viable purchaser. 
Given Baxter's stance with respect to vertical restraints, private suits involving vertical restraints were given special scrutiny for opportunities to move judicial opinions in more tolerant directions.

One of the private vertical restraints cases that was considered for an amicus brief in early 1982 was Rosebrough Monument Co. v. Memorial Park Cemetery Association, 666 F.2d 1130 (1981). Briefly, Rosebrough was a manufacturer of burial monuments and markers and also provided monument foundation preparation services. The Memorial Park Cemetery Association was a trade association of eleven St. Louis area cemeteries. The trade association had a rule, followed by all members, that required purchasers of cemetery plots to purchase also from the cemetery the cemetery's own memorial foundation preparation services.

Rosebrough filed a federal antitrust suit against the association and its members charging that the rule was an illegal conspiracy to enforce illegal tying. The defendants argued that the sale of a cemetery plot and foundation preparation service was a single product and that the tie was justified by the cemeteries' ownership interests in the property and their statutory responsibility to provide perpetual care.

The District Court decision went in favor of the defendants. ${ }^{46}$ Rosebrough appealed, and the Eighth Circuit reversed and held that the trade association's rule was an illegal conspiracy under Section 1 of the Sherman Act and that the tying arrangement was illegal. The defendants were seeking an appeal of the Eighth Circuit's decision to the Supreme Court when the case was reviewed by the Division for a possible amicus brief. $^{47}$

\footnotetext{
${ }^{46}$ Rosebrough Monument Co. v. Memorial Park Cemetery Association, 505 F. Supp. 525 (1980).

${ }^{47}$ Since the Supreme Court has the discretion in most cases as to whether to grant an appeal, it usually first requires briefs submitted by the parties that address the question of whether the Court
} 
The case could have been a good opportunity to distinguish two principles that had been muddied by the Eighth Circuit. On the one hand, the tie of the foundation preparation service to the sale of the plot, if it were specified by an individual cemetery, should not have been objectionable. An individual cemetery would be unlikely to have market power, and the cemetery's interests in maintaining the appearance of the property was a reasonable justification. Even if all of the cemeteries came to this conclusion, so long as they did so independently with no hint of collusion, this would still be unobjectionable. But there was no sensible reason why all of the cemeteries needed to agree that they would all observe this tying arrangement through their trade association rule. That agreement had all of the indicia of an illegal conspiracy. So the Eighth Circuit's decision was only half right, and a clarification would have been useful. ${ }^{48}$

But the Division had limited time and attention resources, and it did not file a brief.

Subsequent events were as follows: The defendants' request for Supreme Court review was denied (457 U.S. 1111 [1982]). The case returned to the District Court, where the judge entered an order that enjoined the tying and specified a set of rules indicating what standards the cemeteries could set with respect to foundation preparation services. ${ }^{49}$ Rosebrough was unhappy with any specification of rules, hoping that the specifics would be left to each cemetery, and was also unhappy with some of the rules that had been specified; Rosebrough again appealed to the Eighth Circuit, which affirmed the

should consider the appeal. The Division was considering the possibility of an amicus brief at this first stage.

${ }^{48}$ Also, as was discussed above, Baxter's activities and philosophy with respect to vertical restraints had generated considerable political hostility. An amicus brief that indicated that the Division was not prepared to bless all vertical restraints under all circumstances might have had some value.

49 Rosebrough Monument Co. v. Memorial Park Cemetery Association, 1983-2 Trade Cases 
District Court's general power to set rules but then modified and overturned some of them as unduly favoring the defendants. ${ }^{50}$ The distinction between the conspiracy among the cemeteries in agreeing on the tying arrangement and the propriety of an individual cemetery's tying arrangement was never addressed.

This was a missed opportunity.

\section{Epilogue}

My experience at the Antitrust Division during 1982-1983 was an exciting, fascinating, and rewarding one. I learned a lot from the economists and lawyers at the Division during my nineteen months of service. I returned to NYU in the fall of 1983 a better economist with a much deeper appreciation for the complexities and challenges of antitrust economics, antitrust law, and antitrust policy and administration.

There were many achievements during my tour of duty that I continue to remember with great pride. There were also multiple frustrations and disappointments. The net was strongly positive.

\section{$\underline{\text { References }}$}

Adelman, M.A. (1959) "Economic Aspects of the Bethlehem Opinion," Virginia Law Review, 45, 684-696.

Areeda, Phillip and Donald F. Turner (1975) "Predatory Pricing and Related Practices under Section 2 of the Sherman Act," Harvard Law Review, 88, 697-733.

65,732 .

50 Rosebrough Monument Co. v. Memorial Park Cemetery Association, 1984-1 Trade Cases 66,019 . 
Baker, Jonathan B. (1998) "Econometric Analysis in FTC v. Staples," mimeo.

Becker, Gary S. (1968) "Crime and Punishment: An Economic Approach," Journal of Political Economy, 76, 169-217.

Becker, Gary S. and George J. Stigler (1974) "Law Enforcement, Malfeasance, and Compensation of Enforcers," Journal of Legal Studies, 3, 1-16.

Benston, George J. (1982) "Accounting Numbers and Economic Values," Antitrust Bulletin, 27, 161-215.

Besen, Stanley M., E. Jane Murdoch, Daniel P. O'Brien, Steven C. Salop, and John Woodbury (1999) "Vertical and Horizontal Ownership of Cable TV: Time Warner-Turner (1996)," in John E. Kwoka, Jr., and Lawrence J. White, eds., The Antitrust Revolution: Economics, Competition, and Policy, 3rd edn. New York: Oxford University Press, 452- 475.

Brennan, Timothy J. (1987) "Why Regulated Firms Should Be Kept out of Unregulated Markets: Understanding the Divestiture in United States v. AT\&T," Antitrust Bulletin, 32, 741- 793.

Brennan, Timothy J. (1990) "Cross-Subsidization and Cost Misallocation by Regulated Monopolists," Journal of Regulatory Economics, 2, 37-51.

Brennan, Timothy J. (1995) "Is the Theory Behind U.S. v AT\&T Applicable Today?" Antitrust Bulletin, 40, 455-482.

Brock, Gerald W. (1975) The U.S. Computer Industry: A Study of Market Power. Cambridge, Mass.: Ballinger.

Dalkir, Serdar and Frederick R. Warren-Boulton (1999) "Prices, Market Definition, and the Effects of Merger: Staples-Office Depot (1997)," in John E. Kwoka, Jr., and Lawrence J. White, eds., The Antitrust Revolution: Economics, Competition, and Policy, 3rd edn. New York: Oxford University Press, 143-164.

DeLamarter, Richard T. (1986) Big Blue: IBM's Use and Abuse of Power. New York: Dodd, Mead.

Elzinga, Kenneth G. and Thomas Hogarty (1973) "The Problem of Geographic Market Delineation," Antitrust Bulletin, 18, 45-81.

Fisher, Franklin M. (1984) "The Misuse of Accounting Rates of Return: Reply," American Economic Review, 74, 509-517.

Fisher, Franklin M. and John J. McGowan (1983) "On the Misuse of Accounting Rates of Return 
to Infer Monopoly Profits," American Economic Review, 73, pp. 82-97.

Fisher, Franklin M., John J. McGowan, and Joen E. Greenwood, (1983) Folded, Spindled, and Mutilated: Economic Analysis and U.S. v. IBM. Cambridge, Mass.: MIT Press.

Hausman, Jerry A., (1997) "Valuing the Effect of Regulation on New Services in Telecommunications," Brookings Papers on Economic Activity: Microeconomics, 1-38.

Hausman, Jerry A. and Gregory K. Leonard (1997) "Documents versus Econometrics in Staples," mimeo.

Horowitz, Ira (1981) "Market Definition in Antitrust Analysis: A Regression Based Approach," Southern Economic Journal, 48, 1-16.

Kaysen, Carl and Donald F. Turner (1959) Antitrust Policy. Cambridge, Mass.: Harvard University Press.

Lohr, Steve (1998) "Antitrust Case Relies Heavily on Events at a 1995 Meeting," New York Times, October 20, C4.

Lynk, William J. (1999) "Tying and Exclusive Dealing: Jefferson Parish Hospital v. Hyde," in John E. Kwoka, Jr., and Lawrence J. White, eds., The Antitrust Revolution: Economics, Competition, and Policy, 3rd. edn. New York: Oxford University Press, 342-363.

MacKie-Mason, Jeffrey K. and John Metzler (1999) "Links between Vertically Related Markets: Kodak (1992)," in John E. Kwoka, Jr., and Lawrence J. White, eds., The Antitrust Revolution: Economics, Competition, and Policy, 3rd edn. New York: Oxford University Press, 386-408.

Morse, M. Howard (1998) "Vertical Mergers: Recent Learning," Business Lawyer, 53, 1217- 1247.

Nelson, Philip B. and Robert D. Stoner (1999) "Defense Industry Rationalization: Lockheed ～Martin (1995) in John E. Kwoka, Jr., and Lawrence J. White, eds., The Antitrust Revolution:

Economics, Competition, and Policy, 3rd edn. New York: Oxford University Press, 430-451.

Noll, Roger G. and Bruce M. Owen (1994) "The Anticompetitive Uses of Regulation: United States v. AT\&T (1982)," in John E. Kwoka, Jr., and Lawrence J. White, eds., The Antitrust Revolution: The Role of Economics, 2nd edn. New York: HarperCollins, 328- 375.

Pindyck, Robert S. and Daniel L. Rubinfeld (1997) Microeconomics, 4th edn. Saddle River, ～N.J.: Prentice-Hall.

Pittman, Russell W. (1984) "Predatory Investment: U.S. vs. IBM," International Journal of 
Industrial Organization, 2, 341-365.

Preston, Lee (1994) "Territorial Restraints: GTE Sylvania," in John E. Kwoka, Jr., and

Lawrence J. White, eds., The Antitrust Revolution: The Role of Economics, 2nd edn. New York: HarperCollins, 311-327.

Salop, Steven C. and David T. Scheffman (1983) "Raising Rivals' Costs," American Economic Review, 73, 267-71.

Salop, Steven C. and David T. Scheffman (1987) "Cost-Raising Strategies," Journal of Industrial Economics, 36, 19-34.

Stigler, George J. (1964) "A Theory of Oligopoly," Journal of Political Economy, 72, 55-69.

Stocking, George W. and Willard F. Mueller (1955) "The Cellophane Case and the New Competition," American Economic Review, 45, 29-63.

Tate, Cassandra (1981) "Gannett in Salem: Protecting the Franchise," Columbia Journalism Review, 20, 51-56.

Telser, Lester G. (1960) "Why Should Manufacturers Want Fair Trade?" Journal of Law \& Economics, 3, 86-105.

Temin, Peter (1987) The Fall of the Bell System: A Study in Prices and Politics. New York: Cambridge University Press.

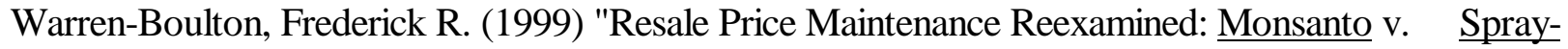
Rite," in John E. Kwoka, Jr., and Lawrence J. White, eds., The Antitrust $\underline{\text { Revolution: }}$

Economics, Competition, and Policy, 3rd edn. New York: Oxford University Press, 364-385.

Werden, Gregory J. (1993) "Market Delineation under the Merger Guidelines: A Tenth Anniversary Retrospective," Antitrust Bulletin, 38, 517-555.

Werden, Gregory J. (1999) "Market Definition under the Merger Guidelines: Monopoly Cases and Alternative Approaches," Review of Industrial Organization, forthcoming.

White, Lawrence J. (1981) "Vertical Restraints in Antitrust Law: A Coherent Model," $\underline{\text { Antitrust }}$ Bulletin, 26, 327-45.

White, Lawrence J. (1985a) "Resale Price Maintenance and the Problem of Marginal and Inframarginal Customers," Contemporary Policy Issues, 3, 17-25.

White, Lawrence J. (1985b) "Antitrust and Video Markets: The Merger of Showtime and the Movie 
Channel as a Case Study," in Eli Noam, ed., Video Media Competition: $\quad$ Regulation, Economics, Competition. New York: Columbia University Press, 338-363.

White, Lawrence J. (1989) "The Revolution in Antitrust Analysis of Vertical Relationships: $\quad$ How Did We Get from There to Here?" in Robert J. Larner and James W. Meehan, eds., Economics and Antitrust Policy. New York: Quorum, 103-121.

White, Lawrence J. (1994) "Application of the Merger Guidelines: The Proposed Merger of CocaCola and Dr Pepper," in John E. Kwoka, Jr., and Lawrence J. White, eds., The Antitrust Revolution: The Role of Economics, 2nd edn. New York: HarperCollins, 76- 95.

White, Lawrence J. (1999a) "Wanted: A Market Definition Paradigm for Monopolization ～Cases," Computer Industry, forthcoming.

White, Lawrence J. (1999b) "Economic Analysis in Antitrust Litigation Support: The Federal Trade Commission's 1986 Challenge to the Proposed Merger of Coca-Cola and Dr Pepper," in Daniel. Slottje, ed., The Role of the Academic Economist in Litigation Support. Amsterdam: North Holland, forthcoming.

Williamson, Oliver E. (1968) "Economics as an Antitrust Defence: The Welfare Tradeoffs," American Economic Review, 58, 18-36. 